\title{
CHINA'S DEBT TRAP PADA BELT AND ROAD INITIATIVE \\ (BRI) MELALUI MODEL TRIBUTARY SYSTEM ALA \\ DINASTI MING-QING DALAM PEMBANGUNAN \\ INFRASTRUKTUR DI TIMOR LESTE
}

\author{
Ade Priangani $^{1}$, Kunkunrat ${ }^{2}$, Rangga MS Saputra ${ }^{3}$ \\ Hubungan Internasional, FISIP, Universitas Pasundan \\ Email: ade.priangani@unpas .ac.id
}

\begin{abstract}
Abstrak
Sejak reformasi China yang dilakukan oleh Deng Xiaoping pada tahun 1978 dan dilanjutkan oleh Xi Jinping yang lebih aktif pada tahun 2013, dengan membentuk jalur ekonomi sutra baru Belt and Road Initiative (BRI) dengan tujuan menciptakan kerjasama dan interdependensi serta harmoni pada tatanan kawasan Asia-Pasifik dan Global. Landasan BRI ini adalah salah satu bentuk romantisasi sejarah pada masa dinasti Han dengan jalur ekonomi sutra lama. Akan Tetapi kepentingan BRI terhadap negara-negara partner menjadi ancaman tersendiri dengan adanya "Debt trap" atau jebakan Utang yang dilakukan oleh China alih-alih bantuan infrastuktur. Sehigga BRI adalah salah satu model "Tributary system" gaya baru ala Dinasti Ming-Qing yang dimana jebakan utang adalah salah satu pengabdian diri pada China sebagai negara inti. Hasil analisis menjelaskan bahwa pengaruh terhadap Timor Leste menjadi ancaman dengan meningkatnya utang sebesar 13 persen pada tahun 2016, namun dibantah oleh Timor Leste dan China sendiri yang dimana jebakan utang adalah konstruksi subjektivitas dari kekhawatiran AS dan sekutu terhadap dominasi China.
\end{abstract}

Kata Kunci : BRI; Debt trap: Tributary System; Timor Leste

\begin{abstract}
Since China's reforms carried out by Deng Xiaoping in 1978 and continued by the more active Xi Jinping in 2013, by forming a new silk economic road, the Belt and Road Initiative (BRI) with the aim of creating cooperation and interdependence and harmony in the Asia-Pacific regional order. and Global. The foundation of BRI is a form of romanticization of history during the Han dynasty with the old silk economy. However, BRI's interest in partner countries has become a separate threat with the existence of a "Debt trap" or debt trap carried out by China instead of infrastructure assistance. As a result, BRI is one of the new Ming-Qing dynastystyle "tributary system" models where debt trap is one of dedicating oneself to China as a core country. The results of the analysis explained that the influence on Timor Leste was a threat with an increase in debt by 13 percent in 2016, but it was
\end{abstract}


denied by Timor Leste and China themselves, where the debt trap is a construction of subjectivity from US and allied concerns about China's domination.

Keywords: BRI; Debt trap: Tributary System; Timor Leste

\section{PENDAHULUAN}

China yang sebelumnya dikenal menerapkan sosialisme China tulen ala Mao Zedong mengalami perubahan sejak masa Deng Xiaoping pada tahun 1978, yaitu dengan menerapkan kaige kaifang (reformasi dan keterbukaan), yang pada akhirnya telah menjadi satu kebijakan politik yang mampu mnciptakan kejayaan ekonomi politik dan militer China. Sistem pemerintahan di rejim Deng sangat unik karena menggabungkan dua sistem, yaitu sosialis-komunis pada kegiatan politik dan militer dan liberalis-kapitalis pada ekonomi (Mühlhahn, 2019, hal. 496-497; Shambaugh \& Yahuda, 2008, hal. 127).

Kebijakan China zaman Deng, menjadi salah satu acuan atau prinsip yang dilanjutkan oleh para penerusnya, termasuk masa Xi Jinping. Xi Jinping mengimplementasikan pemikiran Deng, dengan jalan membentuk geostrategi yang menguntungkan bagi negara-negara sekitar China dengan menghidupkan kembali jalur sutra baru sebagai kekuatan ekonnomi dan kerjasama dalam harmoni China yaitu membuat Belt And road Initiative/ One Belt One Road (yidai yilu). BRI ini menjadi salah satu geostrategi sekaligus geoekonomi China untuk meningkatkkan power pada kekuatan ekonomi politik China dalam infrastruktur ekonomi darat sebagaimana pada jalur sutra pada masa dinasti Han dan jalur sutra baru yang meliputi kawasan maritim diantaranya jalur ekonomi laut melalui infrastruktur pelabuhan dan rute pelayaran di negara partner. Misi-misi dibentuknya BRI yang secara garis besar diinterpretasikan dalam kerangka menciptakan strategi ekonomi dan pertukaran pengetahuan, teknologi, sosialbudaya, dan harmoni perdamaian untuk menciptakan nilai-nilai interdependensi dibawah institusi BRI (CHA, 2017, hal. 488-489).

Akan tetapi kemanfaatan dari BRI yang menciptakan interdependensi dan kerjsama dalam harmoni perdamaian antara negara partner dalam jalur sutra, 
menjadi salah satu ancaman bagi negaraa partner sendiri dan menjadi peluang bagi China untuk memaskimalkan power China sebagai kepentingan nasional untuk menjayakan kembali kejayaan China semasa Era dinasti Han, Ming, dan Qing dengan model yaitu Chinese Debt Trap atau disebut jebakan utang China sebagai model dari "Trbutary System" gaya baru dengan dalih bantuan dan pinjaman infrasktruktur negara berkembang sebagai anggota BRI untuk mengkiblatkan diri melalui upeti untuk menjadi negaraa peripheral China. Hal itu sebagaimana yang terjadi pada Pelabuhan di Sri Lanka dan juga Pakistan yang gagal membayar pinjaman dari utang China. Alhasil pelabuhan tersebut diambil alih China selama 99 tahun. Selain itu banyak negara lain yang terncam terkena jebakan utang China seperti Timor Leste yaitu pelabuhan air dan empat jalur jalan raya dan kontrak pinjaman pada industri gas alam cair yang didanai oleh China Railway Construction Corp sebesar 943 Juta Dollar AS (Hunt, 2019).

Dalam tulisan ini cenderung menggunakan paradigma konstruktivisme dengan pendekatan Marxisme yang melihat bagaimana jebakan utang China adalah kepentingan nasional China sebagaimana Tribtary System pada Zaman Dinasti Ming dan Qing yang menyebabkan terjadinya strukturalisme antara China sebagai negara pada kelas borjuis mendorong Timor Leste untuk melakukan ketergantungan pada China dengan jebakan utang melalui dana pinjaman infrastruktur Timor Leste sebagai negaraa proletar berkembang.

Adapun landasan teoritis yang dipergunakan dalam tulisan ini adalah konstruktivisme. Konstruktivisme adalah salah satu paradigmaa yang melengkapi kekurangan pada paradigmaa liberalisme dan realisme bahwa fenomena pada hubungan internasional muncul tidak terjadi begitu saja, tetapi ada peristiwa pada konstuksi sosial yang dibentuk dari agen dari nilai, norma, sejarah, bahasa, dan maksud dari suatu negara dalam melakukan interaksi pada sistem internasional dan begitu juga anarki. Artinya, bahwa konstukrtivisme melihat bahwa hubungan internasional bukan hanya pada fenomena yang berasal dari kepentingan ekonomi dan keamanan saja, tetapi faktor sosiologis dapat membentuk interaksi antar aktor dalam hubugan internasonal (Hadiwinata, 2017 : 260; Viotti \& Kauppi, 2012). 
Para pemikir dari kosntruktivisme antara lain seperti Nicolas Onuf dalam bukunya yang berjudul "World of Our Making: Rules and Rule in Social Theory and International Relations" pada tahun 1989 mengatakan : satu, simbol-simbol lingusitik mememiliki fungsi yang menentukan apa yang kita bicarakan dan ditangkap pihak lain membentuk dunia sebagaimana yang dipersepsikan, dua, perkataan (spreech act) dan pelbagai turunannya berupa kebijakan dan aturan adalah indicator yang membentuk konstruksi sosial sehingga menempatkan individu sebagai agen dalam penggunaan simbol-simbol ligusitik dalam melakukan interaksi pada sistem internasional dengan negara lain, tiga, speech act sebagai media, ia ditranformasikan melalui bahasa ke dalam pelbagai materi yang ada berupa nilai dan norma menjadi sumber daya atau resources. Sehingga ini menjadi salah satu konstruksi untuk menciptakan distribusi iformasi pada sistem internasional (Onuf, 2013, hal. 18-23).

Dengan demikian, Onuf melihat bahwa simbol-simbol linguistik yang dibentuk dari individu sebagai agen mempengaruhi pada konstruksi pada nilai-nilai intersubjectivity berupa nilai dan norma yang berkembang berupa kebijakan aturan sehingga menghasilkan resources baik dalam maksud dan tujuan yang intensif yaitu pertemanan, ataupun sebaliknya akan menjadi rivalitas.

Dari konstruktivisme yang merupakan landaasan paradigma yang dikembangkan, penulis mengerucutkan kepada pendekatan marxis dalam ekonomi politik internasional dengan konsepnya yaitu teori ketergantungan pada NeoMarxisme. Karena pendekatan marxisme klasik yang berawal dari Karl marx berasumsi bahwa kapitalisme akan hancur dengan dimualinya revolusi sosial oleh kaum proletar atau buruh yang memberontak untuk memiskinkan kelas borjuis yang cenderung mengekspoitasi dan selanjutnya mengekspansinya dalam bentuk mengekspoitasi negara berkembang sebagai negara koloni (Gilpin, 1987 : 40).

Akan tetapi pada pasca perang dingin, justru kapiltalisme dalam ekonomi politik liberalism menjadi semakin mapan dan jiustru negaaa-negara komunis seperti Uni Soviet bubar pada tanggal 26 Desember 1991 beserta negara saelitnya di Eropa Timur. Inilah yang menjadi kritikan sendiri dalam intra-marxisme yang melahirkan aliran yang disebut sebagai Neo-Marxisme atau beberapa para ahli 
menyebutya Struktralisme. Konsep Neo-Marxisme ini melihat dari fenomena bahwa kapitalisme semakin tumbuh berkembang dan pesat karena ditandai dengan berlimpahnya hasil produksi dari negara-negara kapitalis, sehingga mendorong dan memaksa mereka menjualnya ke negara-negara lain dengan imperialism bahkan neo-imperialisme. Maka ini lah yang menjadi salah satu asumsi dasar dari NeoMarxis antara lain: Satu, sistem internasional yang dibentuk dari kelas borjuis dan proletar, membentuk stratifikasi kelas yaitu negara inti sebagai Core Countries merupakan negara maju yang mempunyai power dalam teknologi dan modal. Sedangkan negara berkembang sebagai negara pinggiran sebagai peripheral merupakan negara berkembang yang mempunyai tenaga kerja atau buruh. Dua, negara maju menekan dan mendorong dalam kepentingan ekonomi politiknya baik dalam Foreign Direct Investnment, bantuan, atau pinjaman terhadap negara berkembang yang disebut juga sebagai Least Developed Countries (LDCs) dalam kepentingan untuk menjajah dengan bentuk neo-kolonialisme sehingga mendorong negara berkembang untuk selalu bergantung kepada negara maju. Tiga, negara dunia ketiga atau berkembang/ LDCs menggantungkan nasibnya pada permintaan pasar dan investasi luar ngeeri yang dilakukan oleh negara maju dan justru membuat negara-negara berkembang akan semakin ketergantungan (Gilpin, 1987; Jackson \& Sorensen, 2013 : 299; Viotti \& Kauppi, 2012).

Dengan demikian, dari landasan teoritis tersebut akan membahas bahwa kepetingan politik ekonomi adalah kasus China sebagai negara yang sudah menjadi bigpower dari kebijakan luar negeri yang pragmatis dan ekpansionis sejak masa $\mathrm{Xi}$ Jinping yang dibawakan oleh Deng Xiaoping dengan Kaige kaifang, membentuk suatu konstruksi sosial yang dibentuk dari agen yaitu Xi Jinping dengan meromantisasi sejarah kembali seperti era China pada massa kejayaan dinasti Han, Ming, Qing, yaitu Chinese Dream sebagai sandaran linguistik dengan geostrategi berupa BRI dengan tujuan untuk menciptakan jalur ekonomi, dan stabilitasi ekonomi dan harmoni perdamain dengan negara-negara partner dalam pembangunan infrastruktur.

Kepentingan China dengan BRI adalah bentuk strukturalisme ekonomi yang dilakukan oleh China terhadap negara partnernya dengan bantuan pinjaman namun 
bebralik menjadi jebakan utang yang akhirnya negara partner harus membayar utang dan ketergantungan dalam teknologi dan tenaga kerja dari China yang dimana China menerapkan model tributary system atau sistem negara upeti yang dimana neagra partner BRI mengkiblatkan diri dan mengafirmasi legitimasi serta bergabung dengan power China seabgai Peripheral Countries dengan mengambil alih infrastruktur negara partner jika tidak dapat membayar utang pinjaman inilah neo-marxismenya dalam teori ketergantungan ala model tributary system sebagai upetinya yaitu membayar utang.

\section{PEMBAHASAN}

\section{Sistem Jebakan Utang pada BRI}

Setelah reformasi China yang dilakukan oleh Deng Xiaoping pada tahun 1978 dan dilanjutkan oleh Xi Jinping pada tahun 2013 dengan mega geostrategi sebagai kebijakan luar negeri China, yaitu jalur sutra baru berupa BRI atau OBOR. Negara-negara yang masuk dalam BRI berjumlah 138 negara, diantaranya Indonesia dan juga Timor Leste. Mengacu pada cita-cita Xi Jinping sampai tahun 2049 sebagai visi yang dicapai oleh China sebagai kekuatan global, seperti prediksi dari World Economic Forum dan juga World Bank yang mengatakan bahwa China akan menjadi kekuatan ekonomi kawasan di Asia dan juga global nomor 1 dengan AS berada di urutan ke 3 setelah India di posisi ke-2 (Business Insider \& Martin, 2017; Guo, 2020 : 809-810).

BRI atau OBOR sebagai salah satu geostrategis dan juga gekonomi China masa pemerintahan Xi Jinping, Tujuannya adalah mewujudkan harmonisasi dan perdamaian, kerjasama, interdependensi yang menciptakan kemajuan dan meningkatkan infrastruktur dengan bantuan atau pinjaman dengan model Business to Businness dengan perusahaan Swasta China dan donator atau pendana dari Asia Infrastructure Investnment Bank (AIIB) sebesar 100 Juta dollar.

Banyak pengamat mengatakan bahwa AIIB adalah salah satu penantang dan juga pengganti insitusi moneter dan donator internasional International Monetary Fund (IMF). Namun, skema kerjasama BRI dengan model bantuan dan pinjaman oleh China adalah untuk tercapainya win-win soutuion atau positivie sum games 
terhadap negara berkembang, justru bagi negara berkembang dirasakan sebaliknya, bantuan ibaratnya seperti setan kredit berupa jebakan utang sehingga menjadi zero sum games (Radityo, Rara, Amelia, \& Efraim, 2019).

Pendekatan marxisme seperti yang dijelaskan oleh Vladimir Lenin, bahwa setiap kebijakan ekononi politik antar negara dibentuk dari kepentingan antar kelas, namun dikonstruksikan dalam perkembangan marxisme modern, bahwa kepentingan negara dalam memaksimalisaikan power dalam ekonomi politik membentuk sifat negara maju yang borjuis dan negara berkembang yang proletar dari kekuatan ekonomi dan teknologi, dan kekuatan bantuan ekonomi memunculkan sifat imperialisme gaya baru dengan metode ekonomi sebagai senjata dalam menguasai sumber daya dan juga kepentigan negara berkembang baik dalam pasar yang didalamnya adalah sumber daya pada tenaga kerja dan juga konsumen, sehingga menyebabkan terjadinya ketergantungan sebagaimana yang dijelaskan pada teori ketergantungan (Arbi, 2018; Gilpin, 1987; Jackson \& Sorensen, 2013 : 299).

Kasus jebakan utang yang ditenggarai dilakukan oleh China adalah bentuk imperialisme baru. Cina menggunakan BRI sebagai alat geostrategi dan geoekonomi, telah menyebabkan banyak negara partner yang kesulitan membayar utang dari infrastrukur buah kerjasama dengan China. Yang membuat miris adalah beberapa negara tidak sanggup untuk membayar utang, maka infrastrukturnya akan diambil alih sementara oleh China, meskipun China berasumsi bahwa tindakan ambil alih sementara tersebut adalah upaya memberikan kesempatan negara partner untuk mendapatkan pemasukan dari infrastruktur yang dipegang oleh China.

Hurley dkk dalam tulisannya yang berjudul "Examining the Debt Implications of the Belt and Road Initiative from a Policy Perspective" mereka menuliskan bahwa Cina menginginkan untuk membuat jalur pipa gas dari China ke negara-negara partner dengan membangun pelabuhan Hambantota, di Srilanka, yang disepakati melalui MoU BRI pada bulan Juli 2017 dengan pinjaman 8 Juta Dolar dengan bunga sebesar 6 persen, namun setelah pelabuhan selesai dan Srilanka tidak dapat menyanggupi dengan bayar bunga, maka China mengambil alih 
pelabuhan tersebut dengan alasan untuk memelihara dan menyewa pelabuhan tersebut (Hurley, Morris, \& Portelance, 2018, hal. 20; Panda, 2017).

Dengan demikian Sri Lanka harus merelakan sebagian infrastruktur vital pada pelabuhan tersebut kepada China selama 99 tahun. Maka, banyak negara yang beresiko terkena jebakan utang China seperti pada gambar yang terpampang pada gambar dibawah ini :

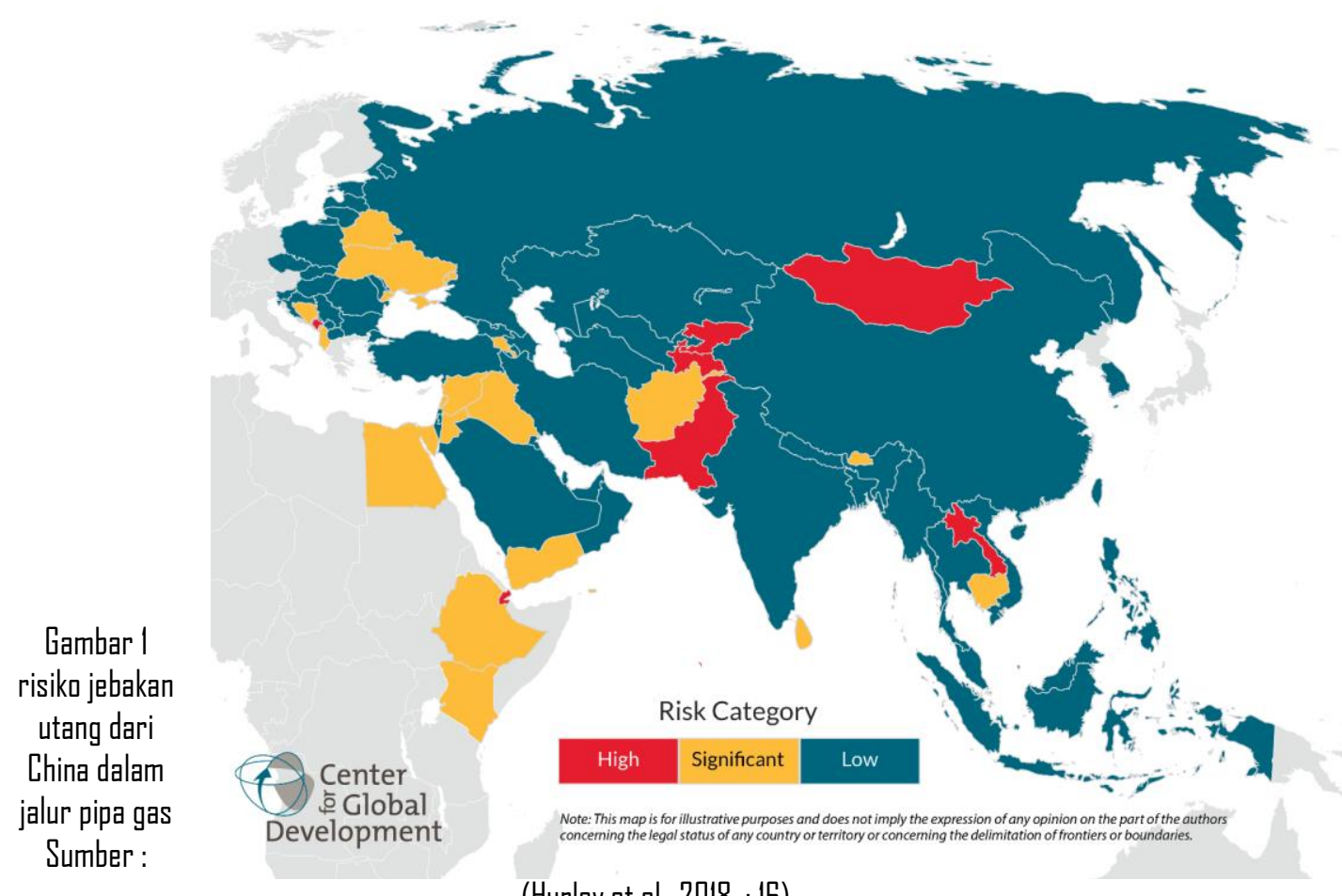

(Hurley et al., 2018, : : I6).

Dari gambar di atas menunjukan bahwa risiko terkena jebakan utang Srilanka masuk ke jajaran risiko sedang yang berwarna Oranye, sedangkan yang berwarna merah (risiko tinggi) yaitu Mongolia, Laos, Kirgistan, Tajikistan, dan Pakistan, sedangan lainnya risiko rendah dengan warna biru. Model yang dilakukan oleh China, membuat negara partner yang tidak memiliki cadangan devisa dan terus mengandalkan pada bantuan dari infrastruktur China, maka akan mengakibatkan utang yang berkelanjutan, dan akibatnya negara tidak mampu mmebayar utang bahkan bunga, sehingga China secara tidak langusng memberikan sistem upeti gaya baru yang pernah dilakukan oleh China pada masa Dinasti Ming dan Qing,dan pada 
fase selanjutnya negara-negara yang membayar utang kepada China mengkiblatkan diri dan melegitimasi China sebagai greatpower seperti pada masa kejayaan kekaisaran terdahulu. Akibat jebakan utang ini, maka China akan melemahkan kekuatan negara-negara lainnya, serta negara-negara berkembang akan menjadi negara sekutu dan loyal terhadap China.

\section{Model Debt Trap BRI pada Infrastruktur Timor Leste}

Jalur Sutra baru (BRI) yang merupakan salah satu jantung ekonomi China sebagaimana pada era dinasti Han, sebagai salah satu reflektivisme sejarah romantisasi yang dilakukan oleh China. Konstruktivisme menjelaskan bahwa perilaku aktor melakukan interaksi atau melakukan suatu kebijakan politiknya karena suatu hal yang dikonstruksi tanpa muncul ke permukaan, hal itu dibentuk dari agen yang diformulasikan pada nilai, norma, ide, bahasa, dan maksud yang dikonstruksikan pada intersubjectivity suatu negara dan hasilnya menjadi salah satu kepentingan nasional negara sebagai power dari nilai-nilai sosiologis (Dugis, 2016; Hadiwinata, 2017).

Hal ini yang dilakukan oleh rejim Xi Jinping bahwa kepentingan BRI mengacu pada cita-cita yang dinamakan dengan "Chinese dream" atau dalam bahasa Mandarin disebut Zhongguo meng yang dilakukan oleh China dengan ajaran-ajaran konfusianismenya sebagai salah satu upaya kebangkitan kembali China, yang sebelumnya telah tenggelam oleh kehadiran kekuatan asing yang telah meduduki China dan juga revolusi kebudayaan yang pernah dilakukan oleh Mao Zedong. Maka, parlemen China melalui Partai Komunis China mendorong konsep yang dikenal quangfang wei waijiao atau disebut sebagai "All-around diplomacy" yang mencita-citakan untuk kepuasan harmoni dan perdamaian (Medeiros, 2008 : 46-47; Nufus, 2014).

Beberapa pengamat melihat bahwa cita-cita China dengan menghidupkan kembali BRI, memandang bahwa BRI adalah model sistem upeti gaya baru dengan model jebakan utang sebagai bentuk pengkiblatan diri dan pengakuan atau legitimasi dalam politik luar negerinya terhadap negara partner BRI adalah sebagai peripheral countries yang juga terus bergantung terhadap struktur utama sistem yaitu China (Yan, 2018). Selain itu, kepentingan China yang juga untuk 
memaksimalkan kekuatan militer dan ekonomi sebagaimana dalam analisis John Mearsheimer mengatakan bahwa negara dipengaruhi oleh sifat alamiah negara sendiri (human nature), namun yang lebih dominan adalah struktur yang mempengaruhi suatu negara, sehingga mendorong negara untuk memaksimalikan kekuatannya (realis defensif) baik secara maksimalisasi kekuatan pada keamanan atau pada kekuatan power atau pengaruh (Realisme Ofensif) (Mearsheimer, 2001).

Tributary system atau sistem upeti adalah sistem kebijakan luar negeri China yang dilakukan pada masa dinasti Ming dan Qing di abad pertengahan. Sistem upeti ini bagi China sendiri adalah cefeng yang artinya atas ke bawah, sehingga sistem tributary adalah sistem polugri China pada zaman dulu yang digunakan untuk menciptakan hubungan secara intensif terhadap negara-negara kecil atau peripheral terhadap kekuatan China sebagai pelindung.

Dalam pemgejawantahannya, sistem upeti ini pada masa dinasti Ming dilakukan dengan cara ekspedisi oleh seorang pelaut handal dalam rangka untuk mencari aliansi atau kawan perdangangan dari negara lain, dengan catatan untuk harmonisasi dan perdamaian. Pada masa kaisar Yongle dinasti Ming, memerintahkan Laksamana Cheng Ho untuk melakukan ekspedisi seperti ke kawasan Asia Tenggara hingga ke Timur Tengah (Fox, 2003 : 79; Xiao, 2011). Setelah Ming runtuh dan digantikan oleh Dinasti Qing, ekspansi wilayah dilakukan pada Masa Kaisar Kangxi, Yongzheng, dan Qianlong yang pertama membuat pendekatan hardpower sebagai sistem upeti dengan kekuatan tentara dengan konsep Tianxia yang artinya dibawah tatanan surga sebagai bentuk tributary system ala Qing, pada saat itu nagara-negara mengabdikan diri pada Qing yaitu Dinasti Joseon, Burma, Nepal, Vietnam, Bhutan, dan kawasan Asia tengah (Jacques, 2009).

Akan tetapi konsep upeti adalah bentuk dari upaya unipolarisasi yang dilakukan oleh China untuk mengeliminasi atau memperkecil pengaruh negaranegara middle power dengan cara sistem upeti sebagai polugrinya, dan juga apabila negara peripheral tidak patuh, ancamannya adalah tindakan intervensi atau kekuatan tangan besi dari militer China pada masa Qing sebagai carrot and stick policy (Constantinou, Kerr, \& Sharp, 2016; Womack, 2012; Zhou, 2011 : 151-152). 
Model sistem inilah yang dilakukan oleh China untuk menghegemoni negara-negara lain, dan bentuk jebakan utang China yang tidak dapat dibayarkan akan diambil alih infrastrukturnya seperti Hambantota di Sri Lanka dan Pelabuhan Gwardar di Pakistan.

Pada kasus Timor Leste yang menjadi kehawatiran sekaligus peluang adalah ketika merdeka tahun 2002 dari Indonesia, China langsung menawarkan bantuan dan juga kerjasama infrastruktur dengan Timor Leste yang menjadi program strategis Nasional Timor Leste 2011-2030 dan juga bersamaan dengan bergabungnya Timor Leste ke BRI pada 2017 melalui Join statement China-Timor Leste yaitu pengakuan legitimasi satu China dan tidak mengakui Taiwan sebagai negara berdaulat (One China Policy), kerjasama infrastruktur, pertukaran budaya, dan pariwisata pada tahun 2014 (Belt and Road Portal, 2017; Government of TimorLeste, 2011).

Analisis liberalisme melihat bahwa dibentuknya BRI sebagai institusi ekonomi dan mengedepankan peran bisnis seperti perusahaan swasta yang terlibat seperti peran AIIB menjadi lembaga pendana dalam membantu pembangunan Timor Leste yang tertinggal sebagai salah satu bentuk dari win-win solution. Dalam pembangunan infrastruktur seperti pembangun jalur pipa gas yang ada Timor Leste yaitu gas Bayu-Undan yang ditaksir mencapai 65 Juta (Galan, 2019).

Para pengamat memandang keuntungan yang dimiliki oleh Timor Leste hanya menghasilkan relative gain semata yang dimana keuntungan China lebih banyak dibandingkan absolute gain sebagaimana yang diharapkan oleh para liberalis ekopolin, sebagaimana yang terjadi pada Sri Lanka dan Pakistan. Yang menjadi ancaman bagi Timor Leste adalah kebijakan BRI sama halnya dengan sifat upeti, yaitu jebakan utang yang semakin membesar, utang Timor Leste sudah menjadi 13 persen di tahun 2016 dalam pembangunan tambang gas Bayu-Undan, dan menjadi keengganan bagi Timor Leste dalam melihat cost and benefit dampak yang ditimbulkan terhadap Timor Leste dari BRI tersebut (Asian Development Bank, 2016).

Selain itu ada ambisi yang dilakukan oleh Li Keqiang sebagai Meneteri Luar Negeri China yang mengatakan bahwa dibentukya BRI adalah sebagai bentuk 
pertahanan keamanan China, hal itu sebagaimana yang ditulis pada The diplomat bahwa peran Exim bank telah memberikan pinjaman sebesar 16 miliar dolar AS dan utangnya menjadi sebuah upeti kepada Beijing sebagai bentuk pengabdian diri terhadap China sebagai negara great power dan memiliki kepentingan, sehingga ini menjadi bantahan bagi Xanana Gusmao yang mengatakan bahwa Timor Leste sama sekali tidak terjebak pada utang, dan sikap China dengan Timor Leste telah menjadi hubungan saudara sejak Timor Leste merdeka. Xanan Gusmao malah lebih mengkhawatirkan terhadap Australia yang selalu mengganggu stabilitas politik dan pembangunan Timor Leste (Hutt, 2020; Roberts, 2019; Suzuki, 2017; Thorne \& Spevack, 2018).

\section{KESIMPULAN}

Proyek geostrategis sekaligus geoekonomi yang dilakukan oleh China pada rezim Xi Jinping pada tahun 2013 adalah salah satu bentuk dari kebangkitan China sebagaimana yang telah dimulai oleh Deng Xiaoping pada tahun 1978. Kebijakan BRI yang dilakukan oleh Xi Jinping pada tahun 2013 adalah bentuk prestasi tersendiri bagi China sebagai kebangkitan ekonomi China dan sebagai wujud pengembalian citra China sebagai kekuatan negara greatpower di kawasan AsiaPasifik bahkan global pada masa dinasti dahulu dengan jalur sutra lama. Akan tetapi dalam melihat jebakan utang China adalah salah satu dari kekhawatiran dari konstruksi rival China sendiri khusunya AS dan sekutunya yang dimana mereka melihat bahwa peran China dengan jebakan utangnya dengan alih-alih bantuan pinjaman infrastruktur terhap negara partnernya yang apabila tidak bisa membayar utangnya, maka akan diambil alih oleh China seperti pelabuhan Hambantota Srilanka dan Gwardar Pakistan. Menyinggung dari analisis AS menjelaskan bahwa China menerapkan Tributary System gaya baru sebagaimana yang pernah dilakukan pada masa dinasti Ming dan Qing dengan bentuk jebakan utang sebagai produk upeti pada pengabdian politiknya terhadap China.

Memang terjadi bantahan yang dilakukan oleh China, dimana China merasa tidak melakukan jebakan utang namun justru memelihara pelabuhan tersebut agar negara partner tidak mengalami masalah pada pembangunan ekonomi dan juga 
pertahanan keamanan nya. Hal itu juga sempat menjadi bantahan pada Timor Leste bahwa tuduhan yang dilakukan oleh jurnalisi barat dan juga nikkei tidak relevan karena justru Timor Leste lebih baik dengan adanya peran China yang telah membantu pembangunannya setelah merdeka.

Jika dilihat dari prisnip liberalisme, BRI adalah bentuk institusi berbasis ekonomi ala China dibawah tatanan tianxia untuk menciptakan harmoni perdaiaman dan interdependesi namun disisi lain, pada neo-marxis melihat bahwa Timor Leste membantah karena sudah terikat oleh kekuatan ketergantungan dari China sendiri melakui BRI sehingga Timor Leste menjadi terkena carrot and stick policy melalui jebakan utang China yang dimana tahun 2016 terakhir utang BRI Timor Leste meningkat 13 persen sebagaimana yang ditulis oleh ADB, inilah upeti yang dimana Timor Leste sebagai negara peripheral mengabdikan diri pada legitimasi China sebagai Xin Da Zhongguo Diguo atau "kekaisaran China Baru”

\section{DAFTAR PUSTAKA}

\section{Buku}

Constantinou, C. M., Kerr, P., \& Sharp, P. (Ed.). (2016). The Sage Handbook of Diplomacy. London: SAGE Publications Ltd.

Dugis, V. (Ed.). (2016). Teori Hubungan Internasional: Perspektif-Perspektif Klasik (Pertama). Surabaya: Cakra Studi Global Strategis.

Fox, M. S. (2003). A Short History of China and South East Asia: Tribute, Trade, and Influence (First). Crows Nest NSW 2065: Allen \& Unwin.

Gilpin, R. (1987). The Political Economy of International Relations - Robert Gilpin - Google Books. https://doi.org/0691077320

Hadiwinata, B. S. (Bob S. (2017). Studi dan teori hubungan internasional : arus utama, alternatif, dan reflektivis (Pertama). Bandung: Yayasan Pustaka Obor Indonesia.

Jackson, R., \& Sorensen, G. (2013). Pengantar Studi Hubungan Internasional (Kelima; D. Suryadiputra \& P. Suyatiman, Ed.). Yogyakarta: Pustaka Pelajar.

Jacques, M. (2009). When China Rules the World: The Rise of the Middle Kingdom and the End of the Western World (First). London: Penguin Group. 
Mearsheimer, J. J. (2001). The Tragedy of Great Power Politics. In Foreign Affairs (First). New York: W.W Norton \& Company.

Medeiros, E. S. (2008). China's Foreign Policy Objectives. In China's International Behavior (hal. 45-60). Diambil dari http://www.jstor.com/stable/10.7249/mg850af.12\%0AJSTOR

Mühlhahn, K. (2019). Making China Modern: From the Great Qing to Xi Jinping. London: The Belknap Press.

Onuf, N. G. (2013). Making sense, making worlds: Constructivism in social theory and international relations. Making Sense, Making Worlds: Constructivism in Social Theory and International Relations, hal. 1-230. https://doi.org/10.4324/9780203096710

Viotti, P. R., \& Kauppi, M. V. (2012). International Relations and Politics. In Pearson Education (Fifth, Vol. https://doi.org/10.1177/0002716289504001014

Shambaugh, D., \& Yahuda, M. (Ed.). (2008). International Relations of Asia. Maryland: Rowman \& Litllrfield publishers, Inc.

\section{Artikel Ilmiah}

CHA, C. (2017). China's Westward March : Strategic Views of One Belt, One Road. The Korean Journal of International Studies, 15(3), 483-500. https://doi.org/10.14731/kjis.2017.12.15.3.483

Galan, E. (2019). The challenges and the opportunities of the Belt and Road initiative for participating countries: the case of Timor-Leste. City University of Macao, 1-19. Diambil dari https://www.researchgate.net/publication/330439739\%0AThe

Guo, B. (2020). A Partocracy with Chinese Characteristics: Governance System Reform under Xi Jinping. Journal of Contemporary China, 29(126), 809823. https://doi.org/10.1080/10670564.2020.1744374

Hurley, J., Morris, S., \& Portelance, G. (2018). Examining the Debt Implications of the Belt and Road Initiative from a Policy Perspective. In CGD Policy Paper $121 \quad$ (No. 121). Diambil dari https://www.cgdev.org/publication/examining-debt-implications-belt-androad- initiative-policy-perspective

Nufus, H. (2014). IMPIAN TIONGKOK: NASIONALISME TIONGKOK MELINTAS BATAS DALAM PEMBANGUNAN TIONGKOK CHINA. Jurnal Penelitian Politik LIPI, 11(2), 43-54. 
Radityo, F., Rara, G., Amelia, I., \& Efraim, R. (2019). GEOPOLITIK TIONGKOK DI KAWASAN ASIA TENGGARA: JALUR PERDAGANGAN (OBOR). Jurnal Asia Pacific Studies, 3(1), 84-97. https://doi.org/10.33541/japs.v3i1.1073

Thorne, D., \& Spevack, B. (2018). Harbored Ambitions - How China's Port Investments are Strategically Reshaping the Indo-Pacific. Diambil dari www.c4ads.org

Womack, B. (2012). Asymmetry and China's Tributary System. The Chinese Journal of International Politics, 5(1), 37-54. https://doi.org/10.1093/cjip/pos003

Xiao, R. (2011). East Asian Order and China's Role: A Historical Perspective. ア ジ ア 研 究 (Ajia Kenkyuu), 57(1). Diambil dari https://www.jaas.or.jp/pdf/57-1/2.pdf

Zhou, F. (2011). Equilibrium Analysis of the Tributary System. The Chinese Journal of International Politics, 4(2), 147-178. https://doi.org/10.1093/cjip/por005

\section{Dokumen Resmi}

Asian Development Bank. (2016). Timor-Leste: 2016-2020. In Country Partnership Strategy.

Government of Timor-Leste. (2011). Timor-Leste Strategic Development Plan 2011 - 2030. In Development. Diambil dari http://timor-leste.gov.tl/wpcontent/uploads/2011/07/Timor-Leste-Strategic-Plan-2011-20301.pdf

Belt and Road Portal. (2017, April 27). Joint Statement between the People's Republic of China and The Democratic Republic of Timor-Leste on Establishing Comprehensive Partnership of Good-neighbourly Friendship, Mutual Trust and Mutual Benefit-Belt and Road Portal. Diambil 12 November 2020, dari https://eng.yidaiyilu.gov.cn/zchj/sbwj/11917.htm

\section{Website Internet}

Arbi, E. (2018). Teori Dependensi: Konsep Hubungan Asimetris Negara Inti dan Periferi. Diambil 8 November 2020, dari Kontekstual website: https://kontekstual.com/teori-dependensi-konsep-hubungan-asimetrisnegara-inti-dan-periferi/

Business Insider, \& Martin, W. (2017). These will be the most powerful economies in the world by 2050. Diambil 14 Oktober 2020, dari World Economic Forum website: https://www.weforum.org/agenda/2017/12/these-will-bethe-most-powerful-economies-in-the-world-by-2050 
Hunt, L. (2019). Timor-Leste must be wary of China's debt trap. Diambil dari UCA News: Union of Catholic Asian News website: https://www.ucanews.com/news/timor-leste-must-be-wary-of-chinas-debttrap/86104\#

Hutt, D. (2020). Timor-Leste's Costly Oil and Gas Ambitions Grind to a Halt. Diambil 12 November 2020, dari The Diplomat website: https://thediplomat.com/2020/10/timor-lestes-costly-oil-and-gasambitions-grind-to-a-halt/

Panda, A. (2017, Desember 11). Sri Lanka Formally Hands Over Hambantota Port to Chinese Firms on 99-Year Lease - The Diplomat. Diambil 12 November 2020, dari https://thediplomat.com/2017/12/sri-lanka-formally-hands-overhambantota-port-to-chinese-firms-on-99-year-lease/

Roberts, G. (2019). Ramos-Horta rejects China influence claims. Diambil 12 November 2020, dari The Singleton Argus website: https://www.singletonargus.com.au/story/6359508/ramos-horta-rejectschina-influence-claims/

Suzuki, J. (2017, Agustus 26). China in East Timor; concern in Indonesia and Australia - Nikkei Asia. Diambil 12 November 2020, dari https://asia.nikkei.com/Politics/China-in-East-Timor-concern-inIndonesia-and-Australia

Yan, L. (2018). Menhan AS : Tiongkok akan Terapkan Sistem Upeti ala Dinasti Ming. Diambil 8 November 2020, dari EpochTimesId website: https://etindonesia.com/2018/06/25/menhan-tiongkok-akan-terapkansistem-upeti-ala-dinasti-ming/ 